\title{
STRATEGI PEMASARAN TELUR AYAM DI UD SATWA TANI KOTA TERNATE
}

\author{
Haryati La Kamisi \\ Dosen Fakultas Pertanian UMMU-Ternate, $\boldsymbol{e}$-mail : -
}

\begin{abstract}
ABSTRAK
Analisis lingkungan internal mencakup kekuatan (Strengths) dan kelemahan (Weakness) produk bersumber dari penilaian internal perusahaan dan untuk lebih valid juga perlu ada penilaian oleh pihak konsumen. Konsumen dapat menilai kelebihan dan kekurangan 4P (Produk, promotion, place, price) secara netral. Tujuan penelitian ini adalah : 1) Mengatahui tanggapan/respon masyarakat terhadap produk telur ayam;2) mengetahui kekuatan, kelemahan, ancaman dan peluang perusahaan dalam memasarkan telur ayam; dan 3) merumuskan strategi pemasaran yang diterapkan oleh perusahaan untuk memasarkan produk telur ayam. Metode analisis yang digunakan adalah anaisis deskriptif, analisis kuantitaif yang meliputi: 1) Matrik Faktor Strategi Eksternal; 2) Matrik Faktor Strategi Internal, Analisis SWOT(Strengths, Weakness, Opportunity, Threats).

Kekuatan yang dimiliki dalam pemasaran telur ayam di UD. SATWA TANI adalah rasa yang enak, harga yang murah, pelayanan yang baik, lokasi yang strategis. Kelemahan yang dimiliki dalam pemasaran telur ayam di UD. SATWA TANI adalah ukuran telur yang kecil, warna kulit telur yang keputih-putihan, ketebalan kulit telur yang tipis. Peluang yang dimiliki dalam pemasaran telur ayam di UD SATWA TANI adalah tidak terpenuhinya permintaan pasar, terpenuhinya gizi masyarakat, minimalisasi anggaran rumah tangga. Ancaman yang dimiliki dalam pemasaran telur ayam adalah respon masyarakat terhadap telur ayam dan tersedianya telur ayam yang tidak menentu.Strategi pemasaran yang ideal setelah dilakukan analisa SWOT yang disesuaikan dengan analisa matrik faktor strategi internal-eksternal pemasaran telur ayam adalah srategi $S$-O (StrengthOpportunities), yaitu dengan mempertahankan dan meningkatkan pelayanan di depo sentral, meningkatkan kualitas produk. Dengan strategi tersebut diharapkan konsumen dapat bertahan dan dapat menarik konsumen baru.
\end{abstract}

\section{Kata Kunci : Strengths, Weakness, Opportunity, Threats}

\section{PENDAHULUAN}

\subsection{Latar Belakang}

Produk-produk pangan yang ada di Indonesia merupakan produk yang ketersediaannya melimpah, tetapi banyak masyarakat yang masih mengalami kekurangan pangan yang mengakibatkan kurang gizi dan terjadinya gizi buruk di masyarakat. Perencanaan untuk meningkatkan pengadaan pangan pada masyarakat adalah penting baik untuk pembangunan nasional maupun untuk kesejahteraan manusia. Zat gizi diperlukan oleh tubuh untuk diubah menjadi energi. Tiga golongan zat gizi yang dapat diubah menjadi energi adalah kerbohidrat, protein, dan lemak. Akan tetapi vitamin, mineral dan air diperlukan untuk membantu merubah zat gizi tersebut menjadi energi. 
Protein adalah bagian penting dari beberapa hormon tubuh. Protein juga memegang peranan dalam mengatur keseimbangan air dalam tubuh dan menjaga kenetralan cairan tubuh. Salah satu sumber protein adalah telur ayam. Pada telur ayam, kandungan protein yang tertinggi ada di bagian kuning telur.

Analisis lingkungan internal mencakup kekuatan (Strengths) dan kelemahan (Weakness) produk bersumber dari penilaian internal perusahaan dan untuk lebih valid juga perlu ada penilaian oleh pihak konsumen. Konsumen sebagai pihak dapat menilai kelebihan dan kekurangan 4P (Produk, promotion, place, price) secara netral. Analisis lingkungan eksternal bersumber dari penilaian pihak manajemen terhadap kondisi eksternal pada umumnya tentang peluang (opportunity) dan ancaman (threats) terhadap perkembangan pemasaran produk telur ayam. Rangkaian analisis eksternal dan internal tersebut meliputi kerangka analisis SWOT. Kerangka analisis SWOT ini menajamkan rumusan strategi pemasaran. Karena mengingat pentingnya manajemen dan strategi pemasaran untuk keberhasilan usaha telur ayam, maka diperlukan penelitian dengan judul "STRATEGI PEMASARAN TELUR AYAM DI UD SATWA TANI KOTA TERNATE".

Perumusan Masalah

Berdasarkan uraian dari latar belakang di atas, maka permasalahan yang muncul adalah sebagai berikut:

a. Bagaimana SWOT UD SATWA TANI dalam memasarkan telur ayam.

b. Bagaimana Strategi Pemasaran yang diterapkan oleh perusahaan untuk memasarkan produk telur ayam.

\subsection{Tujuan Penelitian}

Berdasarkan dengan rumusan masalah di atas, maka tujuan yang akan dicapai dalam penelitian adalah untuk :

a. Untuk mengetehui kekuatan, kelemahan, ancaman dan peluang perusahaan dalam memasarkan telur ayam. b. Untuk merumuskan strategi pemasaran yang diterapkan oleh perusahaan untuk memasarkan produk telur ayam.

Kegunaan Penelitian

Berdasarkan penelitian ini, kegunaan penelitian adalah:

1. Menjadi referensi ilmiah tentang strategi pemasaran yang diterapkan oleh perusahaan dalam memasarkan produk telur ayam.

2. Sebagai referensi ilmiah bagi peneliti lain dan akademisi yang berminat mengkaji tentang agribisnis telur ayam.

\section{METODE PENELITIAN}

\subsection{Metode Penentuan Tempat}

Penelitian ini dilakukan di UD SATWA TANI di Kota Ternate. UD SATWA TANI dipilih sebagai tempat atau obyek penelitian karena merupakan produsen telur ayam di Kota Ternate.

\subsection{Metode Pengambilan Sampel}

Populasi adalah jumlah keseluruhan dari unit analisis yang akan diteliti. Dalam penelitian ini yang akan dijadikan populasi yaitu pihak UD SATWA TANI dan masyarakat yang mengkonsumsi telur ayam. Dalam penelitian ini, unit analisis dari pihak konsumen atau pembeli telur ayam diambil dengan menggunakan metode accidental sampling yaitu pada saat konsumen melakukan pembelian telur ayam karena jumlah populasi konsumen produk telur ayam keberadaannya tidak diketahui secara pasti. Agribisnis telur ayam merupakan suatu sistem, sehingga produk yang dihasilkan oleh produsen tidak hanya dinilai oleh produsen sendiri, tetapi juga harus dilihat dari sisi konsumen. Dengan mengetahui preferensi konsumen terhadap telur ayam, maka produsen dapat menilai kekuatan dan kelemahan yang ada pada produk. Oleh karena itu, responden pada penelitian ini adalah pihak marketing UD SATWA TANI sebanyak 2 orang dan pihak konsumen telur ayam sebanyak 30 orang. 


\subsection{Metode Pengumpulan Data}

Jenis data yang digunakan dalam penelitian ini ada 2 macam, yaitu:

1. Data Primer, yaitu data yang diperoleh dengan cara melakukan wawancara dengan responden dan dengan menggunakan daftar pertanyaan yang telah disiapkan sebelumnya. Daftar wawancara tersebut dipersiapkan agar pertanyaan yang diajukan dapat teratur secara sistematis dan lengkap sehingga dapat mempermudah dalam pengolahan data.

2. Data Sekunder, yaitu data yang diperoleh secara tidak langsung yang diperoleh dari instansi atau lembaga yang berhubungan dengan penelitian.

Untuk memperoleh data atau informasi dari berbagai elemen yang diteliti, maka dalam penelitian ini menggunakan pengumpulan data sebagai berikut:

1. Observasi, yaitu teknik pengumpulan data dengan cara pengamatan secara langsung terhadap obyek penelitian secara sistematis.

2. Wawancara, yaitu pengumpulan data/informasi yang dilakukan dengan cara tanya jawab langsung dengan responden atau narasumber yang berhubungan dengan masalah penelitian yang dilakukan.

3. Penelusuran pustaka, yaitu dengan mempelajari berbagai macam jurnal, buku ilmiah, majalah, dan karya ilmiah yang berkaitan dengan penelitian.

\subsection{Metode Analisis Data}

Metode analisis yang digunakan adalah anaisis deskriptif, analisis kuantitaif yang meliputi: 1) Matrik Faktor Strategi Eksternal; 2) Matrik Faktor Strategi Internal, Analisis SWOT(Strengths, Weakness, Opportunity, Threats).

\section{HASIL DAN PEMBAHASAN \\ 3.1. Faktor-faktor Internal Perusahaan}

Berdasarkan hasil penelitian terhadap responden atau konsumen telur ayam yang ada di UD SATWA TANI diperoleh faktor-faktor internal perusahaan yang meliputi kekuatan dan kelemahan yang dimiliki UD SATWA TANI. Dari hasil tersebut, kemudian disesuaikan dengan keterangan yang diperoleh dari hasil wawancara dengan pihak manajemen UD SATWA TANI. Adapun faktor lingkungan Internal adalah sebagai berikut:

\section{- Kekuatan}

- Rasa telur ayam yang enak. Kebanyakan konsumen lebih suka dengan kuning telur jika dibandingkan putih telur. Terbukti dengan hasil penelitian yang menunjukkan bahwa 24 orang atau $80 \%$ responden atau konsumen mengatakan bahwa rasa telur ayam lebih enak.

- Harga telur ayam diupayakan oleh pihak UD SATWA TANI cukup, dalam arti tidak terlalu mahal dan tidak teralu murah. Akan tetapi responden atau konsumen yang menggunakan telur ayam untuk usaha kue, roti atau makanan berpendapat bahwa harga membeli telur ayam lebih murah, karena dengan menggunakan telur ayam hasil dari usaha kue, roti atau makan tersebut dapat maksimal. Terbukti bahwa 18 orang atau $60 \%$ responden atau konsumen telur ayam yang ada di UD SATWA TANI menilai bahwa harga telur ayam murah.

- Pelayanan yang baik maupun sikap yang ramah dari para penjual dalam melakukan pemasaran telur ayam maupun yang lainnya sangatlah diperlukan. UD SATWA TANI selalu menjaga hubungan kekeluargaan yang baik dengan pelanggan. Terbukti bahwa 29 orang atau 96,67 \% responden atau konsumen menilai bahwa pelayanan UD SATWA TANI baik.

- Lokasi Depo Sentral UD SATWA TANI, dimana lokasi ini berada di tengah-tengah KotaTernate. Terbukti 17 orang atau 56,67 responden atau konsumen menilai bahwa lokasi 
depo sentral UD SATWA TANI sangat strategis. Hal ini merupakan salah satu alasan mengapa para konsumen memilih UD SATWA TANI untuk membeli telur ayam.

\section{- Kelemahan}

- Ukuran telur ayam lebih kecil. Konsumen dalam membeli telur lebih memilih untuk membeli telur yang berukuran besar agar dalam 1 $\mathrm{kg}$ telur konsumen mendapatkan lebih banyak jumlah telurnya, dan telur ayam yang ada di UD SATWA TANI lebih kecil daripada di tempat lain.

- Warna kulit telur ayam yang ada di UD SATWA TANI yang keputihputihan menyebabkan pembeli kurang tertarik untuk membeli telur ayam tersebut.

- Ketebalan kulit telur ayam yang ada di UD SATWA TANI tipis, sehingga mudah pecah. Hal tersebut yang menjadikan kelemahan produk telur ayam yang ada di UD SATWA TANI.

- Promosi yang dilakukan oleh perusahaan untuk produk ini kurang, sehingga masayarakat tidak terlalu mengetahui produk ini dan kebanyakan konsumen mendapat informasi dari saudara atau teman mereka.

\subsection{Faktor Eksternal Perusahaan}

Faktor-faktor eksternal diperoleh dari wawancara dengan pihak menajemen UD SATWA TANI. Faktor eksternal digunakan untuk mengetahui peluang dan ancaman terhadap pemasaran telur ayam yang ada di UD SATWA TANI.

\section{- Peluang}

- Kurang terpenuhinya pemintaan terhadap telur ayam merupakan peluang untuk meningkatkan produksi telur ayam. Faktor yang menyebabkan permintaan naik adalah dengan semakin bertambahnya penduduk, selera konsumen sehingga semakin banyak peluang untuk meningkatnya konsumsi terhadap telur ayam.

- Perencanaan untuk meningkatkan pengadaan pangan pada masyarakat adalah penting baik untuk pembangunan nasional maupun untuk kesejahteraan manusia. Terpenuhinya gizi msyarakat merupakan peluang untuk meningkatnya konsumsi telur ayam.

- Salah satu peluang bagi pemasaran telur ayam adalah minimalisasi anggaran rumah tangga. Dengan semakin mahalnya harga-harga kebutuhan pokok, maka untuk anggaran rumah tangga yang minim, telur ayam merupakan salah satu alaternatif produk untuk dikonsumsi oleh masyarakat.

\section{- Ancaman}

- Ketidaktahuan masyarakat akan telur ayam dapat menjadi ancaman. Karena masyarakat cenderung sulit untuk menerima produk jika belum mengenal produk tersebut dan mereka hanya melihat luar atau fisik produk saja bukan manfaatnya.

- Ketersediaan telur ayam yang ada di UD SATWA TANI terbatas, sehingga hal ini merupakan salah satu ancaman untuk pemasaran telur ayam.

\subsection{Analisa Matrik SWOT}

Secara kuantitatif, berdasarkan analisi matrik strategi internal dan eksternal didapatkan nilai kekuatan 3,90, kelemahan 1,50, peluang 3,34 dan ancaman 1,34. Besarnya nilai faktor internal dan eksternal digunakan untuk pertimbangan dalam merumuskan strategi yang ideal. Kombinasi dari faktor internal dan eksternal ini menghasilkan 4 alternatif strategi yaitu: 1). Strategi S-O yaitu strategi pemasaran dengan menggunakan kekuatan yang dimiliki untuk memanfaatkan peluang yang ada; 2). Strategi W-O yaitu strategi pemasaran dengan mengambil keuntungan dari peluang untuk mengatasi kelemahan yang dimiliki; 3). Strategi S-T yaitu 
strategi pemasaran dengan menggunakan kekuatan untuk menghindari ancaman; 4). Strategi W-T yaitu strategi pemasaran dengan meminimalkan kelemahan dengan menghindari ancaman.

Pada tabel 1, diperoleh kombinasi faktor SWOT yang menghasilkan empat alternatif strategi yaitu:

a. Stratgi S-O, merupakan kombinasi kekutan dan peluang. Strategi ini dibuat dengan menggunakan seluruh kekuatan yang ada untuk memanfaatkan peluang yang ada. Strategi yang dapat diterapkan berdasarkan kekuatan dan peluang yang ada adalah:

- Mempertahankan dan meningkatkan pelayanan. Mempertahankan dan meningkatkan pelayanan yang baik, ramah dan menarik sangat diperlukan. Hal tersebut agar konsumen dapat merasa aman, nyaman dan puas untuk membeli telur ayam di UD Satwa Tani. Oleh karena itu, terciptanya kekeluargaan antar penjual dan pembeli harus dipertahankan dan ditingkatkan.

- Meningkatkan kualitas produk. Meningkatkan kualitas produk digunakan untuk mempertahankan dan merebut pemasaran telur ayam serta untuk mempertahankan maupun mencari konsumen baru. Dengan kualitas yang baik, maka konsumen tidak akan kecewa dengan produk tersebut.

Tabel 1. Matrik Analisa SWOT Strategi Pemasaran Telur Ayam di UD Satwa Tani

\begin{tabular}{|c|c|c|}
\hline EKSTERNAL & 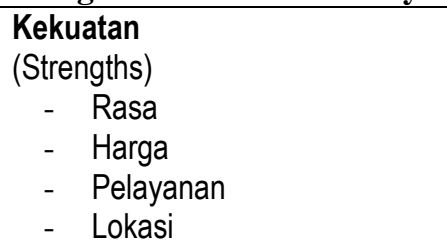 & $\begin{array}{ll}\text { Kelemahan } \\
\text { (Weakness) } \\
\text { - } & \text { Ukuran } \\
\text { - } & \text { Warna Kulit Telur } \\
\text { - } & \text { Ketebalan Kulit Telur } \\
\text { - } & \text { Promosi }\end{array}$ \\
\hline $\begin{array}{ll}\text { Peluang } \\
\text { (Opportunities) } \\
\text { - } & \text { Tidak terpenuhinya } \\
& \text { permintaan pasar } \\
- & \text { Terpenuhinya Gizi } \\
& \text { masyarakat } \\
-\quad & \text { Minimalisasi Anggaran } \\
& \text { Rumah Tangga }\end{array}$ & $\begin{array}{l}\text { Strategi SO: } \\
\begin{array}{l}\text { - Mempertahankan dan } \\
\text { meningkatkan pelayanan di } \\
\text { depo sentral } \\
\text { - } \quad \text { Meningkatkan kualitas telur } \\
\text { ayam }\end{array}\end{array}$ & 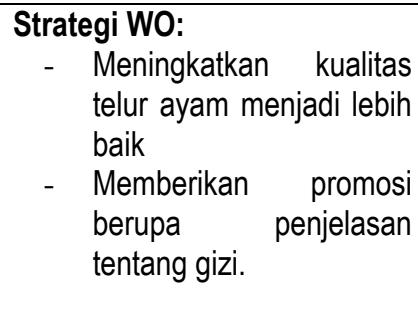 \\
\hline $\begin{array}{ll}\text { Ancaman } \\
\text { (Threats) } \\
-\quad \text { Ketidaktahuan Masyarakat } \\
-\quad \text { Tersedianya Telur Ayam }\end{array}$ & $\begin{array}{cl}\text { Strategi ST: } \\
\text { - } & \text { Meningkatkan pelayanan } \\
& \text { dan Kenyamanan bagi } \\
& \text { konsumen } \\
- & \text { Memberikan potongan } \\
& \text { harga atau bonus bagi } \\
& \text { konsumen yang membeli } \\
& \text { dalamjumlah banyak. }\end{array}$ & $\begin{array}{l}\text { Strategi WT: } \\
\text { - Memberikan papan } \\
\text { nama dan keterangan } \\
\text { produk yang dijual di } \\
\text { Depo Sentral } \\
\text { Melakukan Promosi } \\
\text { terhadap produk telur } \\
\text { ayam. }\end{array}$ \\
\hline
\end{tabular}

Sumber: Data diolah 2009

b. Strategi W-O, merupakan kombinasi kelemahan dan peluang. Strategi ini dibuat dengan meminimalkan kelemahan dan memanfaatkan peluang yang ada. Strategi yang diterapkan berdasarkan kelemahan dan peluang yang ada adalah :
- Meningkatkan kualitas produk. Meningkatkan kualitas produk digunakan untuk mempertahankan dan merebut pemasaran telur ayam serta untuk mempertahankan maupun mencari konsumen baru. Dengan kualitas yang baik, maka 
konsumen tidak akan kecewa dengan produk tersebut.

- Memberikan promosi berupa penjelasan tentang gizi. Dengan diberikannya pengertian tentang gizi kepada masyarakat, maka masyarakat dapat mengetahui tentang bagaimana mereka mencukupi gizi untuk kesehatan mereka. Produk telur ayam diperlukan promosi yang tepat.

c. Strategi S-T, merupakan kombinasi kekuatan dan ancaman. Strategi ini dibuat dengan menggunakan kekuatan untuk mengatasi ancaman. Strategi yang dapat diterapkan berdasarkan kekuatan dan ancaman yang ada adalah:

- Meningkatkan pelayanan dan Kenyamanan bagi konsumen. Peningkatan pelayanan dan kenyamanan oleh karyawan UD Satwa Tani merupakan daya tarik dalam mendapatkan konsumen. Pelayanan dan kenyamanan untuk konsumen dalam berbelanja membuat konsumen merasa terlindungi dalam melakukan transaksi pembelian dengan produk yang juga berkualitas.

- Memberikan potongan harga atau bonus bagi konsumen yang membeli dalam jumlah banyak. Potongan harga atau bonus yang diberikan juga sangat membantu dalam memperoleh konsumen. Potongan harga tersebut tentunya diberikan kepada konsumen yang membeli telur ayam dengan stok yang banyak.

d. Strategi W-T, merupakan kombinasi kelemahan dan ancaman. Strategi ini dibuat dengan meminimalkan kelemahan untuk menghindari ancaman. Strategi yang dapat diterapkan berdasarkan kelemahan dan ancaman yang ada adalah:

- Memberikan papan nama dan keterangan produk yang dijual di Depo Sentral. Hal tersebut merupakan salah satu cara promosi untuk memasarkan telur ayam, karena di depo sentral menunjukkan bahwa depo sentral tersebut adalah milik UD Satwa Tani yang menjual telur ayam.

- Melakukan Promosi terhadap produk telur ayam. Promosi bertujan agar masyarakat dapat mengetahui tentang keberadaaan telur ayam, serta dapat mengetahui respon masyarakat tentang telur ayam.

\section{KESIMPULAN DAN SARAN}

\subsection{Kesimpulan}

Berdasarkan pembahasan hasil penelitian dengan judul Strategi Pemasaran Telur Ayam, maka dapat diambil kesimpulan sebagai berikut:

1. Kekuatan, kelemahan, peluang, dan ancaman dalam pemasaran telur ayam di UD Satwa Tani adalah sebagai berikut:

- Kekuatan yang dimiliki dalam pemasaran telur ayam adalah rasa yang lebih enak, harga yang bersaing dan dapat dijangkau oleh masyarakat, pelayanan yang baik, dan lokasi yang strategis.

- Kelemahan yang dimiliki dalam pemasaran telur ayam adalah ukuran telur yang terlalu kecil, warna kulit telur yang keputih-putihan, ketebalan kulit telur yang tipis dan promosi yang kurang.

- Peluang yang dimiliki dalam pemasaran telur ayam adalah meningkatnya pertumbuhan penduduk, terpenuhinya gizi masyarakat, minimalisasi anggaran rumah tangga.

- Ancaman yang ada dalam pemasaran telur ayam adalah respon masyarakat yang belum banyak mengetahui tentang telur ayam, dan tersedianya telur ayam yang tidak menentu.

2. Strategi pemasaran yang ideal setelah dilakukan analisa SWOT yang disesuaikan dengan analisa matrik faktor strategi internal-eksternal pemasaran telur ayam adalah srategi 
S-O (Strenght-Opportunities), yaitu dengan mempertahankan dan meningkatkan pelayanan di depo sentral, meningkatkan kualitas produk. Dengan strategi tersebut diharapkan konsumen dapat bertahan dan dapat menarik konsumen baru.

\subsection{Saran}

Berdasarkan hasil penelitian maka saran-saran yang dapat disampaikan oleh peneliti adalah:
- Meningkatkan volume penjualan agar kebutuhan konsumen akan telur ayam dapat terpenuhi.

- Meningkatkan kualitas telur ayam agar konsumen dapat bertahan dan puas juga dapat menarik konsumen baru untuk membeli telur ayam yang ada di UD Satwa Tani.

\section{DAFTAR PUSTAKA}

Buckle, K. 1985. Ilmu Pangan. Universitas Indonesia Press ; Jakarta

David, Fred R. 2002. Manajemen Strategis (konsep). PT Prenhallindo ; Jakarta

Gitosudarmo, H Indriyo.1999. Manajemen Pemasaran Edisi Pertama.BPFE ; Yogyakarta

Harper, Laura J. 1986. Pangan, Gizi dan Pertanian. Universitas Indonesia Press ; Jakarta

Muslim, Dudung A. 2009. Memelihara Ayam Kampung sistem battery. Cetakan ke 15 Kanisius; Yogyakarta

Sofjan, Assauri. 1999. (Manajemen Pemasaran (dasar, konsep dan strategi).PT Radja Grafindo Persada ; Jakarta 